PERM JOURNAL OF PETROLEUM AND MINING ENGINEERING

ВЕСТНИК ПНИПУ. ГЕОЛОГИЯ. НЕФТЕЕАЗОВОЕ И ГОРНОЕ ДЕЈО

ISSN 2224-9923

Volume/ Toм 18 №1, 2018

http://vestnik-pstu.ru/geo/

УДК 622.276:612

Article / Статья

(C) PNRPU / ПНИПУ, 2018

\title{
PHYSIOLOGICAL ASPECTS OF HIGH-TECH REFINERY OPERATORS' WORK
}

\section{Larisa V. Plakhova, Nina L. Vishnevskaya, Konstantin A. Chernyi}

Perm National Research Polytechnic University (29 Komsomolskiy av., Perm, 614990, Russian Federation)

\section{ФИЗИОЛОГИЧЕСКИЕ АСПЕКТЫ РАБОТОСПОСОБНОСТИ ОПЕРАТОРОВ ВЫСОКОТЕХНОЛОГИЧНОГО НЕФТЕПЕРЕРАБАТЫВАЮЩЕГО ПРОИЗВОДСТВА}

\section{Л.В. Плахова, Н.Л. Вишневская, К.А. Черный}

Пермский национальный исследовательский политехнический университет (614990, Россия, г. Пермь, Комсомольский пр., 29)

Received / Получена: 12.07.2018. Accepted / Принята: 03.09.2018. Published / Опубликована: 28.09.2018

\section{Key words:}

work ability of operators, monotony syndrome, intra-shift fatigue, mental stress, "physiological cost" of work, hypoxia, asthenia of a prenosological nature.

Work at high-tech refineries is characterized by such the main factors as complexity of workers' duties (pace, nature of mental tasks), intense static and dynamic loads, irrational work regime.

It is known that the decrease in work efficiency is the result of the influence of factors of the labor process (the monotony of external stimuli, long stay in the required working position, restriction of physical activity, relative isolation and sensory insufficiency). That is caused by the development of inhibition in the cerebral cortex and weakening of excitatory process. Arrival of the signal expected is associated with the transition to intensive activities at the control panel according to a specific algorithm or the operator's labor intensity in the long standby mode.

The paper presents results of studies of the basic physiological parameters of the respiratory and cardiovascular systems of operators during 12-hour work shifts. The assessment confirmed the high "physiological cost" of the operators' work activity, myocardial hypoxia observed in the work shift process, reduced mental performance, development of fatigue, therefore, conditions for reducing the reaction rate and possible error actions of the staff in this work process organization.

In addition, the probability of provoking negative changes in the health of operators and possibility of developing a number of cardiovascular diseases, including those caused by production activities, have been confirmed.

There is a need to develop individual strategies to adapt to the labor process, taking into account age and professional features of the activity, as well as the development of rational shift regimes of work and rest for working on 12-hour work schedules taking into account the regular changes in the phase character of working capacity in order to optimize conditions and increase productivity.

Ключевые слова:

работоспособность операторов, синдром монотонии, внутрисменное утомление, умственное напряжение, «физиологическая цена» трудовой деятельности, гипоксия, астения донозологического характера.
К основным факторам деятельности операторов высокотехнологичных нефтеперерабатывающих производств относятся: сложность выполняемой человеком работы (темп, характер мыслительных задач); напряженные статические и динамические нагрузки, нерациональный режим труда.

Известно, что снижение работоспособности является результатом воздействия факторов трудового процесса (монотонность внешних раздражителей, продолжительное пребывание в вынужденной рабочей позе, ограничение двигательной активности, относительная изоляция и сенсорная недостаточность), в основе чего лежит развитие торможения в коре больших полушарий и ослабление возбудительного процесса. Поступление ожидаемого сигнала связано с переходом к интенсивной деятельности за пультом управления по определенному алгоритму или напряженностью труда оператора в режиме длительного ожидания.

В работе представлены результаты выполненных исследований основных физиологических параметров дыхательной и сердечно-сосудистой систем операторов в процессе 12-часовых рабочих смен. Выполненная оценка подтвердила высокую «физиологическую цену» трудовой деятельности операторов, наблюдаемую в процессе рабочих смен гипоксию миокарда, снижение умственной работоспособности, развитие утомления, следовательно, условия для снижения скорости реакции и возможной ошибочности действий персонала при настоящей организации трудового процесса имеются.

Кроме того, подтверждена вероятность провоцирования негативных изменений здоровья операторов и возможность развития ряда сердечно-сосудистых заболеваний, обусловленных в том числе и производственной деятельностью.

Имеется необходимость разработки индивидуальных стратегий адаптации к трудовому процессу с учетом возрастных и профессиональных особенностей деятельности, а также разработки рациональных внутрисменных режимов труда и отдыха для работающих по 12-часовым рабочим графикам с учетом закономерных изменений фазовости работоспособности с целью оптимизации условий и роста производительности труда.

Larisa V. Plakhova - PhD in Biology, Associate Professor at the Department of Life Safety (tel.: +007 952 33644 80, e-mail: larisa-2570@mail.ru). The contact person for correspondence.

Nina L. Vishnevskaya - Doctor of Medicine, Professor of the Department of Life Safety (tel.: +007 908273 01 20, e-mail: charry14@mail.ru).

Konstantin A. Chernyi - Doctor of Engineering, Professor, Head of the Department of Life Safety (tel.: +007 902 479 12 11, e-mail: chernyy_k@mail.ru).

Плахова Лариса Викторовна - кандидат биологических наук, доцент кафедры безопасности жизнедеятельности (тел.: +007 9523364480 , е-таil: larisa-2570@mail.ru). Контактное лицо для переписки.

Вишневская Нина Леонидовна - доктор медицинских наук, профессор кафедры безопасности жизнедеятельности (тел.: +007 9082730120 , е-таil: charry14@mail.ru).

Черный Константин Анатольевич - доктор технических наук, профессор, заведующий кафедрой безопасности жизнедеятельности (тел.: +007 9024791211 , e-mail: chernyy_k@mail.ru) 


\section{Introduction}

The value of operator's job in various areas of professional activity increases constantly. A man's role in the management of technological processes does not decrease, but becomes of great importance [1-6]. Studies show that while performing operator's duties against the background of intense mental activity, high level of professional responsibility for possible erroneous actions personnel suffers monotony and hypokinesia [3, 6-12]. Another important feature of the operator's job should be noted. That is work in a continuous standby mode, which complicates the above-mentioned employee conditions. Transition to 12-hour shifts enhances the development of intra-shift fatigue [13-17].

Due to the mentioned above, research on the problem of mental performance in various conditions of professional activity remains relevant [3, 18-21].

Fatigue that develops among operators should be considered as a physiological state after intensive and prolonged labor mobilization of the body. [22, 23]. However, the special role of operator's work is associated with the need to minimize possible erroneous actions, since it has been proven that against the background of fatigue, the number of errors increase [24-27]. In some studies, this type of fatigue is diagnosed as asthenia of a prenosological or reactive nature, which occurs after excessive mental or mental stress, in violation of work and rest, systematic lack of sleep, adaptation to new climatic conditions etc. In papers that state is called informational neurosis, manager syndrome, white-collar syndrome [2, 28-30].

It is known that acute oxygen starvation is an attribute of intense mental work, so the more functional elements in the processing system of spatial, visual, verbal information, the less effective it will be under the conditions of hypoxia. In connection with the foregoing, the energy deficit in brain cells and cardiovascular system, created by intense mental work, will affect the mental work ability of operators, since it is known that acute oxygen starvation contributes to intense mental work [3, 7, 29, 31, 32].

In the general system of intellectual functioning running memory is the key and most sensitive component that determines the effectiveness of professional activity [33, 34]. At the same time, there is no attention paid to the study of mechanisms of the performance dynamics and the error-free operator's actions $[3,24,35]$.

The purpose of this study is to assess the operator's work ability using informative physiological parameters and to justify possible ways to prevent fatigue of workers.

\section{Research data and methods}

The studies were performed at a large industrial enterprise during 12-hour working shifts with the participation of the operators of the main control panel. Studies were conducted in groups of operators and shift supervisors, in total 60 people took part.

During the assessment of physiological parameters of the body in the dynamics of work shifts blood saturation was determined by the method of pulse oximetry, lung capacity, blood pressure, heart rate, dynamometry, blood circulation efficiency (BCE) and double multiplication - the Robinson index (IR) were calculated.

Pulse oximetry was performed during determination of one of the main indicators of the normal functioning of the body (saturation of arterial blood with oxygen). The measurement of this indicator was performed on equipment of the MD300C series: MD300C2.

Pulse oximetry allows to determine the concentration of oxygen in arterial blood and pulse rate. The norm saturation is the same for adults and is equal to $95-98 \%$.

Determination of this parameter has some peculiarities related to the fact that the blood of an adult, in addition to restored hemoglobin and oxyhemoglobin, contains at least two more types of hemoglobin that are not involved in oxygen transport: methemoglobin (MetHb) and carboxyhemoglobin $(\mathrm{COBb})$. Excluding pathological 
conditions, these fractions are contained in the blood in fairly low concentrations: MetHb $0.2-0.6 \%, \mathrm{COHb}-0-0.8 \%$. Overload hypoxia is physiological and can develop with intense mental work, when cells vigorously consume oxygen. Most likely, this phenomenon can be attributed not to the state, but to the symptom of a temporary decrease in the oxygen content in the body in the process of intense mental labor. Therefore, the control of oxygen content can be used as an indicator of the dynamics of fatigue during labor shifts $[25,29,36]$.

Indirectly, the moment when hypoxia occures is confirmed by calculated indicators, which are used by us for a visual objective assessment based on the results of a physiological survey of workers during labor shifts. The BCE and Robinson index (double multiplication) are between the indicators. Basically, the BCE is essentially a minute volume of blood, which normally is $2,600 \mathrm{ml} / \mathrm{min}$ and increases with fatigue. The calculation of the indicator, $\mathrm{ml} / \mathrm{min}$, is carried out according to the formula

$$
\mathrm{BCE}=(\mathrm{SP}-\mathrm{DP}) \mathrm{bpm},
$$

where SP - systolic blood pressure value, $\mathrm{mm} \mathrm{Hg}$; DP - diastolic blood pressure, $\mathrm{mm} \mathrm{Hg}$.

Robinson Index (or double multiplication, $\mathrm{DM})$, cond. units, as an indicator characterizing the mechanical activity of the heart and blood circulation apparatus as a whole, indirectly indicates the consumption of oxygen by the myocardium and is calculated by the formula

$$
\mathrm{DM}=(\mathrm{SP} \cdot \mathrm{HR}) / 100 \text {, }
$$

where SP - systolic blood pressure value, $\mathrm{mm} \mathrm{Hg}$; HR - heart rate for 1 minute, $\min ^{1}$. Criteria for the indirect evaluation of a double product are average values - from 76 to 89 cond. units; above average -75 and less; below average 90 and above.

\section{Results and discussion}

Study results are presented in the table. Estimation of the vital capacity of the lung (VC) among operators of different departments showed that deviations from the proper $\mathrm{VC}$ are within $\pm 3-7 \%$. Therefore, these values can be regarded as a normal value, since the reduction of $\mathrm{VC}$ to $80 \%$ of the proper value should be considered physiologically significant.

The state of fatigue of workers can be established by a number of physiological indicators of the activity of the cardiovascular and respiratory systems, and the calculation of the $\mathrm{BCE}$ and Robinson index allows visual presentation of the results. Usually it is $86.8 \pm 15$. The smaller the Robinson index, the higher the limiting aerobic potencies and the level of the individual's somatic health. In terms of the age it does not undergo noticeable changes, as the HR decreases with age, and the SD increases.

Analysis of the values of the Robinson index in the table showed that oxygen consumption by the myocardium during the work activity of the operators undergoes adverse changes. It was noted that even at the beginning of day and night shifts oxygen consumption by the myocardium is below the average normal level; there is an intensive subsequent decrease in this indicator by the end of 12 -hour work shifts. Perhaps this phenomenon is associated with the action of the identified syndromes of monotony and hypokinesia that accompany the work of the operators.

Consequently, the calculation of the Robinson index in the studied contingent of workers showed indirectly the presence of conditions for the formation of a symptom of chronic hypoxia. That may ultimately indicate adverse changes in the cardiovascular system and indicate in the long run a possible provocation of the development of chronic pathology [2].

The calculation performed indicates that normal values of BCE are 1.5-2.0 times larger during the day and night shifts. Therefore, fatigue accompanying the hard work of operators is so great at the very beginning of work shift and during the activity, which can lead to an increase in erroneous actions. Earlier we noted that requirements to results of occupational duties became stricter. That leads to a particular intensive stress and overstrain of workers' body and indicates a high "physiological price" of this work $[13,14,37]$. 
Physiological indicators of operators during work shifts and shift supervisors during the labour

\begin{tabular}{|c|c|c|c|c|c|c|c|c|c|c|}
\hline \multirow{2}{*}{ Division } & \multirow{2}{*}{ Shift } & \multirow{2}{*}{ Shift period } & \multicolumn{2}{|c|}{$\begin{array}{c}\text { Blood saturation } \\
\text { oxygen }\end{array}$} & \multirow{2}{*}{ Lung capacity, 1} & \multirow{2}{*}{$\begin{array}{l}\text { Arterial } \\
\text { pressure }\end{array}$} & \multirow{2}{*}{$\begin{array}{l}\text { Robinson } \\
\text { index, } \\
\mathrm{ml} / \mathrm{min}\end{array}$} & \multirow{2}{*}{$\mathrm{BCE}$} & \multirow{2}{*}{$\begin{array}{l}\text { Pulse, } \\
\text { bpm }\end{array}$} & \multirow{2}{*}{$\begin{array}{l}\text { Dynamo- } \\
\text { meter, } \mathrm{N}\end{array}$} \\
\hline & & & $\begin{array}{l}\text { before } \\
\text { walk }\end{array}$ & $\begin{array}{l}\text { after } \\
\text { walk }\end{array}$ & & & & & & \\
\hline \multicolumn{11}{|c|}{ Operators } \\
\hline \multirow{4}{*}{ ORD } & \multirow{2}{*}{ Daytime } & Beginning & 98 & 99 & $\begin{array}{c}4.23 \\
\text { (standard } \pm 5 \%)\end{array}$ & $153 / 86$ & 108.63 & 4,970 & 71 & 48 \\
\hline & & End & 98 & 99 & $\begin{array}{c}4.43 \\
\text { (standard } \pm 3 \%)\end{array}$ & $139 / 81$ & 91.74 & 3,828 & 66 & 48 \\
\hline & \multirow{2}{*}{ Night } & Beginning & 98 & 99 & $\begin{array}{c}4.6 \\
\text { (standard } \pm 3 \%)\end{array}$ & $135 / 80$ & 94.5 & 3,850 & 70 & 46 \\
\hline & & End & 98 & 100 & $\begin{array}{c}4.83 \\
\text { (standard } \pm 6 \%)\end{array}$ & $132 / 76$ & 88.44 & 3,752 & 67 & 47 \\
\hline \multirow{4}{*}{ PIRD } & \multirow{2}{*}{ Daytime } & Beginning & 98 & 100 & $\begin{array}{c}4.75 \\
\text { (standard } \pm 5 \%) \\
\end{array}$ & $135 / 76$ & 87.75 & 3,835 & 65 & 51 \\
\hline & & End & 98 & 100 & $\begin{array}{c}4.36 \\
\text { (standard } \pm 4 \%)\end{array}$ & $133 / 76$ & 91.77 & 3,933 & 69 & 52 \\
\hline & \multirow{2}{*}{ Night } & Beginning & 98 & 100 & $\begin{array}{c}4.87 \\
\text { (standard } \pm 6 \%)\end{array}$ & $130 / 70$ & 85.8 & 3,960 & 66 & 50 \\
\hline & & End & 98 & 100 & $\begin{array}{c}4.77 \\
(\text { standard } \pm 5 \%)\end{array}$ & $127 / 67$ & 80.01 & 3,780 & 63 & 51 \\
\hline \multicolumn{11}{|c|}{ Supervisors } \\
\hline \multirow{4}{*}{ ORD } & \multirow{2}{*}{ Daytime } & Beginning & 97 & 100 & $\begin{array}{c}3.71 \\
\text { (standard } \pm 18 \%)\end{array}$ & $134 / 81$ & 95.14 & 3,710 & 71 & 52 \\
\hline & & End & 98 & 100 & $\begin{array}{c}4.25 \\
\text { (standard } \pm 5 \% \text { ) }\end{array}$ & $133 / 81$ & 95.76 & 3,744 & 72 & 53 \\
\hline & \multirow{2}{*}{ Night } & Beginning & 97 & 99 & $\begin{array}{c}4.2 \\
\text { (standard } \pm 6 \%)\end{array}$ & $129 / 76$ & 90.3 & 3,710 & 70 & 49 \\
\hline & & End & 99 & 100 & $\begin{array}{c}4.46 \\
\text { (standard } \pm 3 \%)\end{array}$ & $145 / 82$ & 94.25 & 4,095 & 65 & 49 \\
\hline \multirow{4}{*}{ PIRD } & \multirow{2}{*}{ Daytime } & Beginning & 96 & 99 & $\begin{array}{c}4.48 \\
\text { (standard } \pm 3 \%)\end{array}$ & $116 / 75$ & 84.68 & 2,993 & 73 & 49 \\
\hline & & End & 97 & 99 & $\begin{array}{c}3.82 \\
(\text { standard } \pm 16 \%)\end{array}$ & $117 / 74$ & 91.26 & 3,096 & 78 & 50 \\
\hline & \multirow{2}{*}{ Night } & Beginning & 97 & 99 & $\begin{array}{c}4.37 \\
(\text { standard } \pm 4 \%)\end{array}$ & $128 / 70$ & 92.16 & 4,176 & 72 & 50 \\
\hline & & End & 98 & 100 & $\begin{array}{c}4.11 \\
\text { (standard } \pm 7 \%)\end{array}$ & $130 / 70$ & 97.5 & 4,500 & 75 & 49 \\
\hline
\end{tabular}

Note: ORD - oil refining division; PIRD - primary oil refining division.

The identified changes in working capacity were confirmed by results of physiological studies and showed a decrease in the speed of visualhearing and motor signal differentiation and an increase in the number of erroneous actions of operators by the end of the work shift $[14,37]$.

Methods of processing spatial and verbal information, involve more links (actions) and more difficult way to obtain the desired result. Therefore, hypoxia, like a tiring cognitive load, has a more intensive negative effect on mental performance indicators $[1,19,27,36,38]$. Consequently, hypoxia in the studied contingent of operators should be regarded as a possible cause of the erroneousness of actions.

In terms of dynamics of the physiological reactions of the body of the shift supervisors the results obtained can be correlated mostly with people of 50 years old. Despite the overall fairly stable picture of the physiological indicators of the cardiovascular and respiratory systems, the design parameters allow to objectively present and evaluate it. Thus, the Robinson index showed that the activity of the cardiovascular system of workers takes place under conditions of oxygen deficiency (hypoxia). This 
phenomenon is observed in both day and night shifts, and myocardial hypoxia is detected at the beginning of work shift. Therefore, this contingent workers present a symptom of chronic hypoxia. No particular differences related to the age of the examined were revealed at this stage of the research. The BCE among shift supervisors increases during the shift by $1-7 \%$ of the initial value, which indicates body fatigue at the beginning and during the labor. Neverthelles, the intensity of fatigue is much lower than the operators of shift managers. It is supposed that this is caused by adaptation of the organism to the conditions of work, accumulation of experience, possible use of individual methods of preparing for a shift (including inter-shift and pre-shift rest).

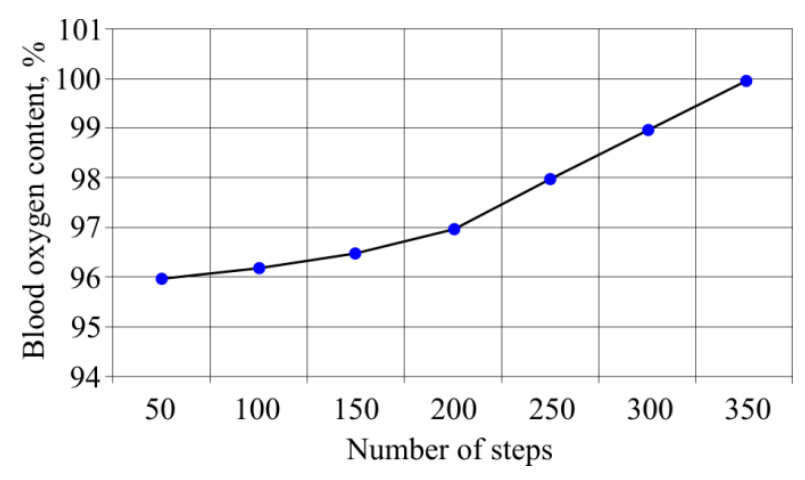

Fig. Oxygen content in peripheral blood depending on the number of steps during a walk

It is worth saying, that actual and must be VC of the shift supervisors are different. Deviations from the proper values range from 3 to $18 \%$. Probably, the indicator plays a certain role in myocardial hypoxia development. A walk in the air should be considered as one of the ways to prevent fatigue, improve performance and oxygenation of blood. We carried out a study of blood saturation during walks with a given number of steps. It was established that in all subjects the blood saturation with oxygen up to $100 \%$ occurred when moving up to 350 steps, and this condition was achieved in 6 minutes of walking (Fig.).

\section{Results}

The studies carried out confirmed the high "physiological price" of the operators' work activity, hypoxia of the myocardium observed during the work shifts, reduced mental performance, and development of fatigue. Therefore, there are conditions for reducing the reaction rate and possible erroneous actions of the personnel.

Thus, the readiness of the body to perform the responsible hard work of the operator of a hightech enterprise, the state of the body during labor shifts do not meet the required parameters and may cause errors in the performance of direct professional duties.

In addition, the probability of provoking negative changes in the health of operators and the possibility of developing the number of cardiovascular diseases, including those caused by production, have been confirmed.

There is a need to develop individual strategies to adapt to the labor process, taking into account age and professional features of the activity.

The studies carried out indicate the need to develop rational internal shift modes of work and rest for an operator that work for 12 hours. Regular changes in the phase of working capacity have to be considered in order to optimize conditions and increase productivity.

\section{References}

1. Onaev S.T., Balaeva E.A., Ismailova A.A., Kurmangalieva D.S., Shadetova A.Zh. Psikhofiziologicheskie kriterii, opredelyayushchie rabotosposobnost rabotnikov vakhtovogo proizvodstva [Psychophysiologic criteria determining performance in shift team workers]. Meditsina truda i promyshlennaya ekologiya, 2012, no.7, pp.38-40.

2. Costa G. Shift work and occupational medicine: an overview. Occupational Medicine, 2003, vol.53, no.2, pp.83. DOI: $10.1093 / \mathrm{occmed} / \mathrm{kqg} 045$
3. Duncan J., Emslie H., Williams P., Johnson R., Freer C. Intelligence and the Frontal Lobe: The organization of goal-directed behavior. Cognitive Psychology, 1996, no.30, pp.257-303. DOI: 10.1006/cogp.1996.0008

4. Spasennikov V.V. Psikhologiya truda, ekonomicheskaya psikhologiya, ergonomika [Labor psychology, economic psychology, ergonomics]. Moscow, PerSe, 2012, 302 p.

5. Tretyakov V.P. "Chelovecheskiy faktor" v energetike kak zveno obespecheniya bezopasnoy raboty 
energeticheskogo obekta ["Human factor" in the energy sector as a link to ensure the safe operation of an energy facility]. Chelovecheskiy faktor: problemy psikhologii $i$ ergonomiki, 2013, no.4(67), pp.136-138.

6. Evenko V.V., Zhenchevskaya N.V., Spasennikov V.V. Problemy obekta $\mathrm{V}$ inzhenerno-psikhologicheskikh i ergonomicheskikh issledovaniyakh: retrospektivnyy analiz [Object problems in engineering, psychological and ergonomic research: a retrospective analysis]. Innovatsionnye metody i modeli v ekonomicheskoy psikhologii, ergonomike, proizvodstvennom menedzhmente, 2013, pp.35-57.

7. Boronoev V.V. O prognoze rabotosposobnosti cheloveka-operatora [On the prediction of the health of a human operator]. Vestnik Buryatskogo gosudarstvennogo universiteta, 2005, no.9, pp.95-101.

8. Gemelli K.K., Hilleshein E.F., Lautert L. The effect of shift work on the health of workers: a systematic review. Rev. Gaucha Enferm., 2008, vol.29, no.4, pp.639-646.

9. Dul I., Bruder R., Buckle P., Carayon P., Falson P., Marras W.S., Wilson J.R., Doelen B.A. Strategy for human factors. Ergonomics: developing the discipline and procession. Ergonomics, 2012, vol.55, no.4, pp.377-395. DOI: $10.1080 / 00140139.2012 .661087$

10. Zhenchevskaya N.V. Otsenka dinamiki rabotosposobnosti operatorov po elektrofiziologicheskim pokazatelyam [Evaluation of the dynamics of the work ability of operators by electrophysiological indicators]. Psikhologiya truda, inzhenernaya psikhologiya $i$ ergonomika 2014. Trudy mezhdunarodnoy nauchnoprakticheskoy konferentsii. Ed. A.N. Anokhin, P.I. Paderno, S.F. Sergeev. Tver, Mezhregionalnaya obshchestvennaya organizatsiya "Ergonomicheskaya assotsiatsiya", 2014, pp.148-155.

11. Yatsenko M.V. Vliyanie faktorov vneshney sredy $i$ individualno-tipologicheskikh osobennostey na umstvennuyu rabotosposobnost i sostoyanie bioelektricheskoy aktivnosti golovnogo mozga [The influence of environmental factors and individual typological features on mental performance and the state of bioelectric activity of the brain]. Abstract of Ph. D. thesis. Barnaul, 2002, 22 p.

12. Brummer et al. Brain cortical activity is influenced by exercise mode and intensity. Med. Sci. Sports Exerc., 2011, vol.43, no.10, pp.1863-1872. DOI: 10.1249/MSS.0b013e3182172a6f

13. Vishnevskaya N.L., Chernyy K.A., Plakhova L.V. Metody opisaniya psikhofiziologicheskikh osobennostey operatorov avtomatizirovannykh kompleksov pri modelirovanii protsessov vliyaniya chelovecheskogo faktora [Methods for describing the psychophysiological characteristics of operators of automated complexes when modeling the processes of influence of the human factor]. Izvestiya YUFU. Tekhnicheskie nauki, 2017, no.4 (189), pp.262-270.
14. Vishnevskaia N.L., Plakhova L.V., Polednak P., Bernatic A. Evaluation of joint effect of factors of small intensity of production environment and labor process on work ability and error of action of operators of high-tech energy complexes. Perm Journal of Petroleum and Mining Engineering, 2017, vol.16, no.2, pp.183-190. DOI: $10.15593 / 2224-9923 / 2017.2 .9$

15. Klimesch W. Alpha-band oscillations, attention, and controlled access to stored information. Trends in cognitive sciences, 2012, vol.16, no.12, pp.606-617. DOI: 10.1016/j.tics.2012.10.007

16. Schupp H., Cuthbert B., Bradley M., Hillman Ch., Hamm A., Lang P. Brain processes in emotional perception: motivated attention. Cognition and emotion, 2004, vol.18, no.5, pp.593-611. DOI: $10.1080 / 02699930341000239$

17. Kozlova I.Yu. Professionalnaya nadezhnost personala. Sposoby otsenki [Professional reliability of staff. Evaluation methods]. Materialy itogovoy konferentsii voenno-nauchnogo obshchestva slushateley $i$ ordinatorov $i$ fakulteta. Saint Petersburg, Voennomeditsinskaya akademiya, 2007, pp.63-64.

18. Chernov S.Yu., Batishcheva G.A., Goncharova N.Yu. Aktualnye problemy ispolzovaniya resursov zdravookhraneniya dlya obespecheniya "professionalnogo dolgoletiya" lits operatorskikh professiy [Actual problems of using health care resources to ensure the "professional longevity" of the people who work as operators]. Sistemnyy analiz $i$ upravlenie $v$ biomeditsinskikh sistemakh, 2011, vol.10, no.4, pp.763-769.

19. Petrukovich V.M., Ivanov A.O., Zotov M.V., Fedorov S.I. Vliyanie gipoksii na umstvennuyu rabotosposobnost operatorov s razlichnymi strategiyami pererabotkiinformatsii $\mathrm{v}$ operativnoy pamyati [The impact of hypoxia on the mental performance of operators with different strategies for processing information in short term memory]. Vestnik $S P b G U, 2015$, seriya 12, iss.3, pp.27-37.

20. Basar E., Basar-Eroglu C. et al. Brain oscillations in perception and memory. Int. Psychophysiol., 2000, vol.35 (2-3), pp.95-124.

21. Rilk A.J., Soekadar S.R., Sauseng P., Plewnia C. Alpha coherence predicts accuracy during a visuomotor tracking task. Neuropsychologia, 2011, vol.49, no.13, pp.3704-3709. DOI: 10.1016/j.neuropsychologia.2011.09.026

22. Kulganov V.A. Integralnaya otsenka funktsionalnogo sostoyaniya i rabotosposobnosti operatorov [Integral assessment of the functional state and work ability of operators]. Trudy voenno-kosmicheskoy akademii im. A.F. Mozhayskogo, 2016, no.650, pp.192-198.

23. Dawai S.Z., Taha Z. The effect of job and environmental factors on job satisfaction in automotive industries. International Journal of Occurational 
Safety and Ergonomics, 2006, no.3, pp.138-146. DOI: $10.1080 / 10803548.2006 .11076687$

24. Gorbov F.D. O "pomekhoustoychivosti" operatora [About the operator "noise immunity"]. Natsionalnyy psikhologicheskiy zhurnal, 2011, no.1, pp.90-92.

25. Gutyanskiy G.S. Fiziologicheskie metody i sposoby korrektsii funktsionalnogo sostoyaniya i reabilitatsii operatora (obzor) [Physiological methods and ways to correct the functional state and rehabilitation of the operator (review)]. Chelovecheskiy faktor: problemy psikhologii i ergonomiki, 2017, no.2 (82), pp.56-64.

26. Dorokhov V.B., Arsenev G.N., Zakharchenko D.V., Lavrova T.P., Tkachenko O.N., Dementienko V.V. Psikhomotornyy test dlya issledovaniya zritelno-motornoy koordinatsii pri vypolnenii monotonnoy deyatelnost [Psychomotor test for the study of visual-motor coordination in the performance of monotonous target tracking activities]. Zhurnal vysshey nervnoy deyatelnosti imeni I.P. Pavlova, 2011, vol.61, no.4, pp.1-9.

27. Kozlova I.Yu. Professionalnaya nadezhnost personala. Sposoby otsenki [Professional reliability of staff. Evaluation methods]. Materialy itogovoy konferentsii voenno-nauchnogo obshchestva slushateley $i$ ordinatorov $i$ fakulteta. Saint Petersburg, Voennomeditsinskaya akademiya, 2007, pp.63-64.

28. Strongin G.L., Yakimovich N.V. Kak izmerit ustalost? [How to measure fatigue?]. Aviaglobus, 2002, no.10.

29. Qin Y., Ma R.S., Ni H.Y. Locating the impairment of human cognitive function during hypoxia. Space Med. Med. Eng., 2010, vol.14, iss.3, pp.218-220.

30. Whitney D., Goodale M.A. Visual motion due to eye movements helps guide the hand. Exp. Brain Res, 2005, 162(3), pp.394-400. DOI: 10.1007/s00221-004-2154-0

31. Ovcharov V.E., Yakimovich N.V. Povyshennoe utomlenie kak sledstvie intensivnoy rabochey nagruzki u pilotov dvukhmestnykh ekipazhey [High fatigue as a result of intense workload for pilots of two-seater crews]. Aktualnye voprosy meditsinskogo obespecheniya bezopasnosti poletov. Tezisy dokladov konferentsii. Irkutsk,2003, pp.103-110.

32. Stuss D.N., Knight R.T. Principltes of frontal lobe function. Oxford, Oxford University Press, 2002, $630 \mathrm{p}$.

33. Rzaev D.O., Rumyantseva E.R. Psikhofiziologicheskoe obosnovanie gipoksicheskoy trenirovki $\mathrm{s}$ podvodnym pogruzheniem $\mathrm{v}$ protsesse obshchefizicheskoy podgotovki kursantov [Psychophysiological rationale for hypoxic training with scuba diving in the process of general physical training of cadets]. Sovremennye problemy nauki i obrazovaniya, 2017, no.5, available at: http://science-education.ru/ ru/article/view?id=27050. (accessed 12 June 2018).

34. Dorokhov V.B., Arsenev G.N., Tkachenko O.N., Zakharchenko D.V., Lavrova T.P., Dementienko V.V. Psikhomotornyy test dlya issledovaniya zritelno-motornoy koordinatsii pri vypolnenii monotonnoy deyatelnosti po proslezhivaniyu tseli $2011 \mathrm{~g}$. [Psychomotor test for the study of visual-motor coordination in the performance of monotonous activities to track the target in 2011]. Zhurnal vysshey nervnoy deyatelnosti, 2011, vol.61, no.4, pp.476-484.

35. Chernov S.Yu., Batishcheva G.A., Lavlinskaya L.I. Vliyanie usloviy truda na sostoyanie zdorovya lits operatorskikh professiy [Influence of working conditions on the health status of operators]. Sistemnyy analiz $i$ upravlenie v biomeditsinskikh sistemakh, 2011, vol.10, no.4, pp.961-969.

36. Golubev V.N. et al. O vliyanii gipoksicheskikh trenirovok na parametry gipoksicheskoy ustoychivosti [On the effect of hypoxic training on the parameters of hypoxic resistance]. Baroterapiya v kompleksnom lechenii ranenykh bolnykh $i$ porazhennykh. Tezisy dokladov 7 Vsearmeyskoy nauchno-prakticheskoy konferentsii, 12-13 marta 2009 g. Saint-Petersburg, Voennomeditsinskaya akademiya, 2009, pp.110-111.

37. Vishnevskaya N.L., Plakhova L.V., Chernyy K.A. Metodicheskie podkhody k otsenke usloviy i opredeleniyu napryazhennosti truda operatorov vysokotekhnologichnykh opasnykh proizvodstv [Methodical approaches to assessing the conditions and determining the intensity of labor of operators of high-tech hazardous industries]. Zdorove $i$ obrazovanie $v$ XXI veke, 2016, vol.18, no.8, pp.69-71.

38. Nesterov S.V. Vliyanie ostroy eksperimentalnoy gipoksii na mozgovoe krovoobrashchenie i vegetativnuyu regulyatsiyu serdechnogo ritma u cheloveka [Effect of acute experimental hypoxia on cerebral circulation and autonomic regulation of heart rhythm in humans]. Abstract of Ph. D. thesis. Saint-Petersburg, 2004, 20 p.

\section{Библиографический список}

1. Психофизиологические критерии, определяющие работоспособность работников вахтового производства / С.Т. Онаев, Е.А. Балаева, А.А. Исмаилова, Д.С. Курмангалиева, А.Ж. Шадетова // Медицина труда и промышленная экология. - 2012. - № 7. - С. 38-40.

2. Costa G. Shift work and occupational medicine: an overview // Occupational Medicine. - 2003. - Vol. 53, № 2. - P. 83. DOI: $10.1093 /$ occmed/kqg045
3. Intelligence and the frontal lobe: the organization of goal-directed behavior / J. Duncan, H. Emslie, P. Williams, R. Johnson, C. Freer // Cognitive Psychology. - 1996. № 30. - P. 257-303. DOI: 10.1006/cogp.1996.0008

4. Спасенников В.В. Психология труда, экономическая психология, эргономика. - M.: PerSe, 2012. - 302 c.

5. Третьяков В.П. «Человеческий фактор» в энергетике как звено обеспечения безопасной работы 
энергетического объекта // Человеческий фактор: Проблемы психологии и эргономики. - 2013. № 4(67). - С. 136-138.

6. Евенко В.В., Женчевская Н.В., Спасенников В.В. Проблемы объекта в инженерно-психологических и эргономических исследованиях: ретроспективный анализ // Инновационные методы и модели в экономической психологии, эргономике, производственном менеджменте. - Брянск, 2013. - С. 35-57.

7. Бороноев В.В. О прогнозе работоспособности человека-оператора // Вестник Бурятского государственного университета. - 2005. - № 9. - С. 95-101.

8. Gemelli K.K., Hilleshein E.F., Lautert L. The effect of shift work on the health of workers: a systematic review // Rev. Gaucha Enferm. - 2008. - Vol. 29, № 4. - P. 639-646.

9. Strategy for human factors. Ergonomics: developing the discipline and procession / I. Dul, R. Bruder, P. Buckle, P. Carayon, P. Falson, W.S. Marras, J.R. Wilson, B.A. Doelen // Ergonomics. - 2012. - Vol. 55, № 4. P. 377-395. DOI: 10.1080/00140139.2012.661087

10. Женчевская Н.В. Оценка динамики работоспособности операторов по электрофизиологическим показателям // Психология труда, инженерная психология и эргономика 2014: тр. междунар. науч.практ. конф. / под ред. А.Н. Анохина, П.И. Падерно, С.Ф. Сергеева; Межрегиональная общественная организация «Эргономическая ассоциация». - Тверь, 2014. - C. $148-155$.

11. Яценко М.В. Влияние факторов внешней среды и индивидуально-типологических особенностей на умственную работоспособность и состояние биоэлектрической активности головного мозга: автореф. дис. ... канд. наук. - Барнаул, 2002. - 22 с.

12. Brain cortical activity is influenced by exercise mode and intensity / Brummer [et al.] // Med. Sci. Sports Exerc. - 2011. - Vol. 43, № 10. - P. 1863-1872. DOI: $10.1249 / \mathrm{MSS} .0 \mathrm{~b} 013 \mathrm{e} 3182172 \mathrm{a} 6 \mathrm{f}$

13. Вишневская Н.Л., Черный К.А., Плахова Л.В. Методы описания психофизиологических особенностей операторов автоматизированных комплексов при моделировании процессов влияния человеческого фактора // Известия ЮФУ. Технические науки. - 2017. № 4 (189). - С. 262-270.

14. Оценка сочетанного влияния факторов малой интенсивности производственной среды и трудового процесса на работоспособность и ошибочность действий операторов высокотехнологичных энергетических комплексов / Н.Л. Вишневская, Л.В. Плахова, П. Поледняк, А. Бернатик // Вестник Пермского национального исследовательского политехнического университета. Геология. Нефтегазовое и горное дело. - 2017. - Т. 16, № 2. - C. 183-190. DOI: 10.15593/2224-9923/2017.2.9

15. Klimesch W. Alpha-band oscillations, attention, and controlled access to stored information // Trends in cognitive sciences. - 2012. - Vol. 16, № 12. - P. 606-617. DOI: $10.1016 /$ j.tics.2012.10.007

16. Brain processes in emotional perception: motivated attention / H. Schupp, B. Cuthbert, M. Bradley, Ch. Hillman, A. Hamm, P. Lang // Cognition and emotion. - 2004. Vol. 18, № 5. - P. 593-611. DOI: 10.1080/02699930341000239

17. Козлова И.Ю. Профессиональная надежность персонала. Способы оценки // Материалы итоговой конференции военно-научного общества слушателей и ординаторов I факультета / Военно-медицинская академия. - СПб., 2007. - С. 63-64.

18. Чернов С.Ю., Батищева Г.А., Гончарова Н.Ю. Актуальные проблемы использования ресурсов здравоохранения для обеспечения «профессионального долголетия» лиц операторских профессий // Системный анализ и управление в биомедицинских системах. 2011. - Т. 10, № 4. - С. 763-769.

19. Влияние гипоксии на умственную работоспособность операторов с различными стратегиями переработки информации в оперативной памяти / В.М. Петрукович, А.О. Иванов, М.В. Зотов, С.И. Федоров // Вестник СПбГУ. - 2015. - Сер. 12, вып. 3. - С. 27-37.

20. Brain oscillations in perception and memory / E. Basar, C. Basar-Eroglu [et al.] // Int. Psychophysiol. 2000. - Vol. 35 (2-3). - P. 95-124.

21. Alpha coherence predicts accuracy during a visuomotor tracking task / A.J. Rilk, S.R. Soekadar, P. Sauseng, C. Plewnia // Neuropsychologia. 2011. - Vol. 49, № 13. - P. 3704-3709. DOI: 10.1016/j.neuropsychologia.2011.09.026

22. Кулганов В.А. Интегральная оценка функционального состояния и работоспособности операторов // Труды военно-космической академии им. А.Ф. Можайского. - 2016. - № 650. - С. 192-198.

23. Dawai S.Z., Taha Z. The effect of job and environmental factors on job satisfaction in automotive industries // International Journal of Occurational Safety and Ergonomics. - 2006. - № 3. - P. 138-146. DOI: $10.1080 / 10803548.2006 .11076687$

24. Горбов Ф.Д О «помехоустойчивости» оператора // Национальный психологический журнал. - 2011. № 1. - С. 90-92.

25. Гутянский Г.С. Физиологические методы и способы коррекции функционального состояния и реабилитации оператора (обзор) // Человеческий фактор: проблемы психологии и эргономики. - 2017. № 2 (82). - С. 56-64.

26. Психомоторный тест для исследования зрительно-моторной координации при выполнении монотонной деятельности по прослеживанию цели / В.Б. Дорохов, Г.Н. Арсеньев, Д.В. Захарченко, Т.П. Лаврова, О.Н. Ткаченко, В.В. Дементиенко // Журнал высшей нервной деятельности им. И.П. Павлова. - 2011. - Т. 61, № 4. - С. 1-9. 
27. Козлова И.Ю. Профессиональная надежность персонала. Способы оценки // Материалы итоговой конференции военно-научного общества слушателей и ординаторов I факультета / Военно-медицинская академия. - СПб., 2007. - С. 63-64.

28. Стронгин Г.Л., Якимович Н.В. Как измерить усталость? // Авиаглобус. - 2002. - № 10.

29. Qin Y., Ma R.S., Ni H.Y. Locating the impairment of human cognitive function during hypoxia // Space Med. Med. Eng. - 2010. - Vol. 14, iss. 3. - P. 218-220.

30. Whitney D., Goodale M.A. Visual motion due to eye movements helps guide the hand // Exp. Brain Res. - 2005. 162(3). - P. 394 400. DOI: 10.1007/s00221-004-2154-0

31. Овчаров В.Е., Якимович Н.В. Повышенное утомление как следствие интенсивной рабочей нагрузки у пилотов двухместных экипажей // Актуальные вопросы медицинского обеспечения безопасности полетов: тез. докл. конф. - Иркутск, 2003. - C. 103-110.

32. Stuss D.N., Knight R.T. Principltes of frontal lobe function. - Oxford: Oxford University Press, 2002. - 630 p.

33. Рзаев Д.О., Румянцева Э.Р. Психофизиологическое обоснование гипоксической тренировки с подводным погружением в процессе общефизической подготовки курсантов [Электронный ресурс] // Современные проблемы науки и образования. - 2017. - № 5. URL: http://science-education.ru/ru/article/view?id=27050 (дата обращения: 12.06.2018).
34. Психомоторный тест для исследования зрительно-моторной координации при выполнении монотонной деятельности по прослеживанию цели 2011 г. / В.Б. Дорохов, Г.Н. Арсеньев, О.Н. Ткаченко, Д.В. Захарченко, Т.П. Лаврова, В.В. Дементиенко // Журнал высшей нервной деятельности. - 2011. - Т. 61, № 4. - С. 476-484.

35. Чернов С.Ю., Батищева Г.А., Лавлинская Л.И. Влияние условий труда на состояние здоровья лиц операторских профессий // Системный анализ и управление в биомедицинских системах. - 2011. Т. 10, № 4. - С. 961-969.

36. О влиянии гипоксических тренировок на параметры гипоксической устойчивости / В.Н. Голубев [и др.] // Баротерапия в комплексном лечении раненых больных и пораженных: тез. докл. 7-й Всеармейской науч.-практ. конф., 12-13 марта 2009 г. / Военномедицинская академия. - СПб., 2009. - С. 110-111.

37. Вишневская Н.Л., Плахова Л.В., Черный К.А. Методические подходы к оценке условий и определению напряженности труда операторов высокотехнологичных опасных производств // Здоровье и образование в XXI веке. - 2016. - Т. 18, № 8. - С. 69-71.

38. Нестеров С.В. Влияние острой экспериментальной гипоксии на мозговое кровообращение и вегетативную регуляцию сердечного ритма у человека: автореф. дис. ... канд. мед. наук. - СПб., 2004. -20 c.

Please cite this article in English as:

Plakhova L.V., Vishnevskaya N.L., Chernyi K.A. Physiological aspects of high-tech refinery operators' work. Perm Journal of Petroleum and Mining Engineering, 2018, vol.18, no.1, pp.76-84. DOI: 10.15593/2224-9923/2018.3.7

Просьба ссылаться на эту статью в русскоязычных источниках следующим образом:

Плахова Л.В., Вишневская Н.Л., Черный К.А. Физиологические аспекты работоспособности операторов высокотехнологичного нефтеперерабатывающего производства // Вестник Пермского национального исследовательского политехнического университета. Геология. Нефтегазовое и горное дело. - 2018. - Т.18, №1. - C.76-84. DOI: 10.15593/2224-9923/2018.3.7 